\title{
Survivin as a Cancer Vaccine Target
}

\author{
Michael J Ciesielski ${ }^{1} 2^{*}$, Jingxin Qiu ${ }^{3}$ and Robert A Fenstermaker ${ }^{1,4}$
}

${ }^{1}$ Department of Neurosurgery, Roswell Park Cancer Institute and State University of New York School of Medicine and Biomedical Sciences, Elm and Carlton Streets, Buffalo, New York, 14263, USA

2Department of Immunology, Roswell Park Cancer Institute, Elm and Carlton Streets, Buffalo, New York, 14263, USA

${ }^{3}$ Department of Pathology, Roswell Park Cancer Institute, Elm and Carlton Streets, Buffalo, New York, 14263, USA

${ }^{4}$ Center for Immunotherapy, Roswell Park Cancer Institute, Elm and Carlton Streets, Buffalo, New York, 14263, USA

*Corresponding author: Michael J Ciesielski, Roswell Park Cancer Institute, Elm \& Carlton Streets, Buffalo, NY 14263, USA, Tel: 716-845-8850; Fax: 716-845-8980; Email: michael.ciesielski@roswellpark.org

Received date: 20 March 2014; Accepted date: 21 May 2014; Published date: 24 May 2014

Copyright: (c) 2014 Ciesielski MJ, et al. This is an open-access article distributed under the terms of the Creative Commons Attribution License, which permits unrestricted use, distribution, and reproduction in any medium, provided the original author and source are credited.

\begin{abstract}
Survivin expression is associated with a poor prognosis in many cancers. While survivin is being studied as a potentially important target for cancer therapy, its many biological functions in both normal and cancerous cells remain to be fully elucidated. There are at least six specific survivin splice variants that have been identified to date which appear to be self-regulating and may have distinct functions. Several survivin peptide vaccines are currently under development by different groups. Survivin vaccine strategies for the most part have focused upon particular regional epitopes of the molecule that are bound by $\mathrm{MHC}$ class I and can lead to a cytotoxic $\mathrm{T}$ cell response. Immunotherapy targeting survivin is still at an early stage of development; however, several agents are progressing through early phase clinical trials. Recent studies using SurVaxM, a multi-epitope cryptic peptide, survivin, mimic show specific CD8+ T cell responses, as well as specific CD4+ T cell stimulation. Currently SurVaxM is in Phase I clinical trials designed to study its safety, tolerability and immunological effects in patients with survivin-positive recurrent malignant gliomas and multiple myeloma.
\end{abstract}

Keywords: Survivin; Immunotherapy; Peptide; Vaccine; Apoptosis

\section{Survivin}

Survivin is an $16.5 \mathrm{kDa}$ intracellular protein that mediates a number of anti-apoptotic and oncogenic effects [1]. Survivin belongs to the inhibitor of apoptosis protein (IAP) family [2,3]. It acts in concert with the mitotic spindle apparatus to regulate cell division [4] and localizes to the spindle microtubule organizing center (MTOC) during the G2/M phase of the cell cycle $[2,3,5]$. Survivin has also been shown to modulate the function of a number of terminal effector cell death proteases (caspases) leading to an inhibition of apoptosis [3,6-8]. Survivin expression is associated with a poor prognosis in many cancers $[9,10]$. While survivin is being studied as a potentially important target for cancer therapy, its many biological functions in both normal and cancerous cells remain to be fully elucidated.

Survivin appears to function mainly as an anti-apoptotic molecule and its ability to interfere with p53 is one of its most studied molecular action [11-13]. However, the presence of survivin in the nucleus [14]; its interaction with the mitotic spindle [5]; its secondary localization inside mitochondria [15]; its presence in exosomes in plasma [16] observed exosomal release [17]; and the existence of circulating survivin-encoding mRNA [18,19]; and the existence of a many alternative mRNA splice variants all paint a complex picture of the molecule's possible actions. Although expressed during fetal development [1], survivin is rarely detectable in the normal tissues of adult organisms [20]. The cells of many different forms of cancer express survivin [1] and in some cases expression is related to tumor grade $[9,10,21]$. Survivin expression in tumors is associated with a high rate of disease recurrence and resistance to therapy, and it confers significant survival advantage to tumor cells $[22,23]$.

\section{Survivin Cell Biology and Molecular Mechanisms}

Due to its relatively specific expression in cancer cells, survivin presents a therapeutic target. Immunotherapy by active immunization is one promising means by which survivin-expressing cancer cells can be targeted. Vaccines directed against an intracellular protein, such as survivin, target the post-proteasomal processed, fragments of the molecule which are presented at the cell surface by MHC class I or class II molecules [4,21,24-26]. Consequently, the immune system may recognize survivin's processed molecular fragments and produce a cytotoxic cellular response to those tumor cells. However, it is the essential nature of survivin's action that could make it a particularly good immunotherapeutic target $[27,28]$. One of the ways a tumor cell may evade immune recognition is through down-regulation of the target protein. In the case of survivin, this should naturally lead to activation of the apoptotic pathway [29]. While the action of exosomal survivin is not well understood, it may mediate cellular signaling in some way $[16,17]$. Thus, in addition to producing a direct cellmediated antitumor effect, active specific vaccination against survivin could lead to antibody-mediated interference with these actions.

Another interesting feature of survivin resides with the number of splice variants that have been identified to date. There are at least six specific survivin variants which appear to be self-regulating and which may have distinct functions [30,31]. The survivin splice variants are generated through combinations of exons 1-4 with two alternate exons $2 B$ and $3 B$ (Figure 1) [30-32]. Survivin-2B and survivin- $\Delta E x 3$ are two well-studied forms [33-35]. Survivin-2B is formed by the addition of 
an alternate exon 2 and survivin- $\Delta \mathrm{Ex} 3$ is an exon 3 deletion variant which results in a truncated protein due to a frame shifted stop codon [30]. A high ratio of survivin- $\Delta \mathrm{Ex} 3$ to wild-type survivin has been identified in aggressive cancers; whereas, when survivin-2B is predominant over wild-type survivin, a reduced anti-apoptotic potential is observed [33,36-42]. High expression of survivin- $\Delta$ Ex3 has also been correlated with high proliferative activity and tumor recurrence potential, while survivin- $2 \mathrm{~B}$ tends to be associated with a lower rate of tumor recurrence $[34,43,44]$. Splice variants may also affect the cellular localization of the survivin protein $[14,45]$. Survivin-2B preferentially localizes to the cytoplasm, while survivin$\Delta \mathrm{Ex} 3$ preferentially localizes to the nucleus $[14,46]$. Interestingly, high nuclear survivin expression is related to laryngeal cancer recurrence [47]. Wild-type survivin and survivin- $\Delta \mathrm{Ex} 3$ have also been observed to interact within the mitochondria [36]. The subcellular localization of survivin can vary in some cancers. Illustrative of this, three cases of glioblastoma multiforme are shown in Figure 2.

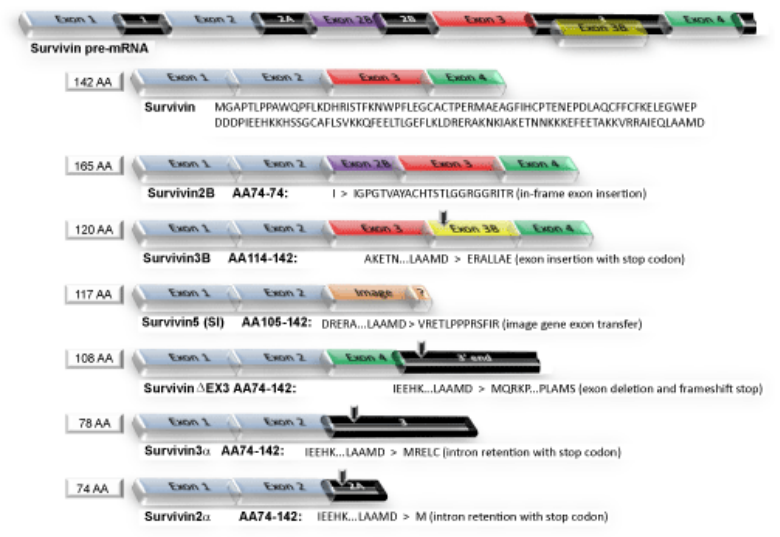

Figure 1: Survivin splice variants described to date. Depiction of survivin pre-mRNA and its derived splice variants. Amino acid sequence alterations from the primary survivin transcript are shown below each splice variant exon structure. Information derived from O15392 (BIRC5_HUMAN) UniProt database [31] and [32].

Survivin- $2 \alpha$ has been shown to attenuate the action of wild-type survivin and to co-localize with it [48]. While it retains anti-apoptotic function, survivin-3B does not appear to be associated with the $\mathrm{G} 2 / \mathrm{M}$ phase, suggesting different regulatory effects of the two molecular forms [49]. Moreover, depletion of cellular survivin does not lead to complementation by the splice variants [50].

Insulin-like growth factor-1 (IGF-1) is able to shift the survivin premRNA splicing program from production of survivin-2B to that of wild-type survivin, thus promoting the cell survival action of IGF-1 [51]. Cumulatively, these observations demonstrate the multifaceted nature of survivin biology and raise the possibility that in addition to the wild-type survivin, the unique survivin epitopes present in these forms may be specifically targetable via active immunotherapy.

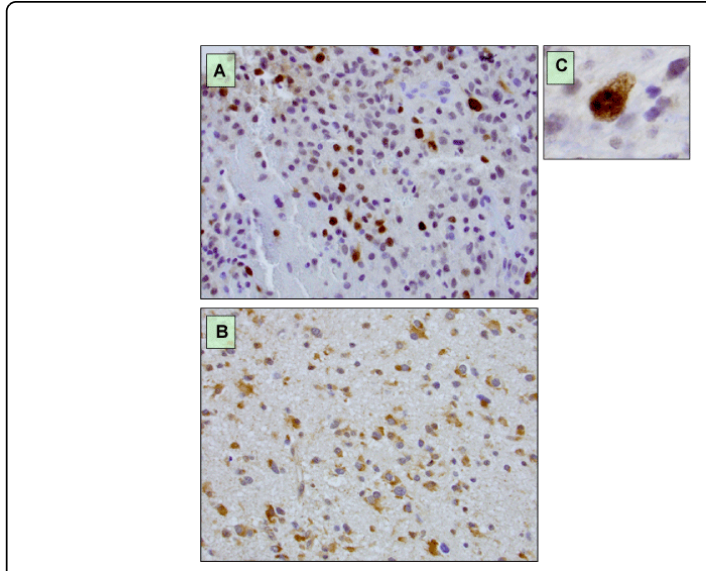

Figure 2: Immunohistochemical staining patterns of glioblastoma multiforme (GBM) formalin-fixed, paraffin embedded tissue specimens for survivin. (A) GBM showing predominant nuclear staining for survivin. (B) GBM with mostly cytoplasmic survivin expression and lack of nuclear staining. (C) Representative high magnification from a third GBM showing a cell with simultaneous cytoplasmic and nuclear survivin expression. [A, B 200x; C, 400x; anti-survivin clone 12C4 (Dako North America, Inc. Carpinteria, CA)].

\section{Survivin Vaccines in Clinical Studies}

A number of anti-tumor vaccine strategies have used cell-surface target molecules like HER2/neu, EGFR and EGFRvIII which are accessible to both cellular and antibody-mediated immune attack [52-56]. If correctly presented on the surface of tumor cells by MHC molecules, epitopes of intracellular proteins that are also recognizable by specific effector $\mathrm{T}$ cells can serve as targets for antitumor immune responses [25,26,57]. For example, studies in patients with malignant melanoma have demonstrated cytotoxic T lymphocytes (CTL) that recognize MHC-I-presented peptides derived from the intracellular protein tyrosinase [58]. Tyrosinase and gp100 are proteins that can serve as antigens that are recognized by CTL in melanoma patients [59-61]. Peptide epitopes from tumor-associated antigens (TAA), including survivin, can be recognized by cytotoxic $\mathrm{T}$ lymphocytes (CTL) in the context of MHC molecules [25,26,62]. Monitoring of T cell reactivity against survivin-derived peptides in a melanoma patient in remission following IL-2 based immunotherapy identified a persistence of functional CTL capable of recognizing surviving [63]. Other auto-reactive CTL responses to survivin have been observed in cancer patients as well [64-66]. Similarly, circulating anti-survivin antibodies have been detected in patients with colon and lung cancer [59-62]. These observations document the natural immunogenicity of survivin and underscore its potential utility as a target for cancer immunotherapy.

A number of survivin-targeting immunotherapeutic strategies have been developed to date. Dendritic cell (DC)-based vaccines are attractive due to the tremendous antigen presentation potential of DC. Dendritic cell vaccines pulsed with apoptotic bodies of cells that overexpressed survivin (as well as Her2, CEA, WT1 and MAGE2) have been studied in non-small cell lung cancer (NSCLC) [67]. This study showed positive immune responses in 10 of 14 patients, along with anecdotal clinical responses [67]. DC loaded with both survivin and 
telomerase peptides have been tested in renal carcinoma where 13 of 27 patients experienced disease stabilization for 8 weeks along with 1 patient who had stable disease for 6 months $[68,69]$. In another study, DC pulsed with survivin and MAGE3 mRNA produced vaccinespecific CD3+ $\mathrm{T}$ cell production in multiple myeloma patients [70]. While detection of survivin-specific T cells in DC vaccine studies are encouraging, it is difficult to dissect the contribution of individual antigens in these reports since most have either included other target antigens along with a survivin CTL epitope (i.e. gp100, Muc1, telomerase and MAGE), or have simply used pulsed crude tumor lysate from survivin-expressing cells.

Several survivin peptide vaccines are also currently under development. In one early study, a patient with pancreatic cancer was vaccinated with a single survivin peptide and experienced a complete remission [71]. An HLA-A ${ }^{\star} 24-$ restricted survivin-2B splice variant vaccine showed safety and produced immune responses in patients with advanced colorectal cancer [72]. Subsequent studies showed this peptide to be effective at stimulating CTL responses in patients with advanced breast cancer, oral and urothelial cancers [73-76]. Most recently, this peptide vaccine has shown promise in metastatic urothelial cancer where 30 patients had significantly better overall survival compared to controls [77]. This particular vaccine utilizes a very specific epitope that is not present in all survivin forms.

Other survivin peptide vaccines have incorporated combinations of HLA class I restricted survivin peptides. A phase II study of one such peptide combination showed prolonged overall survival in metastatic melanoma patients (median survival of 19.6 vs. 8.6 months) [78]. This anti-survivin vaccine peptide mixture (EMD640744) consists of five CTL epitope peptides, each with highly specific HLA class I restrictions [79]. A recent phase I study of EMD640744 in advanced solid tumors showed CD8+ T cell responses in $61 \%$ of patients and stable disease in $28 \%$ of treated patients [79]. A liposome-based adjuvant formulation of survivin peptide mixture known as DPXSurvivac has also induced survivin-specific CD8+ $\mathrm{T}$ cell immune responses in a phase I ovarian cancer study [80]. Further study of that agent is currently ongoing.

While CD8+ CTL responses are powerful anti-tumor targeting agents, CTL responses alone have not led to consistent clinical responses. A number of studies have highlighted the value of $\mathrm{CD} 4+\mathrm{T}$ cells and antibody-based responses in enhancing anti-survivin immunotherapeutic efficacy $[25,26,57,76,81]$. Once CD4+ cells have been activated, they proliferate and produce cytokines (e.g. IFN- $\gamma$, IL-2, and IL-4) that enhance CTL immune responses [82-84]. In addition to simply recruiting $\mathrm{CD} 4+\mathrm{T}$ cells via a generic helper peptide, the presence of MHC class II-restricted CD4+ T cells that are specific for tumor-associated antigens has been recognized to be an important element for providing essential helper factors in eliciting and sustaining cytotoxic $\mathrm{CD} 8+$ responses against tumors $[81,82,85-88]$. Therefore, a vaccine strategy that combines CTL and $\mathrm{CD} 4+$ antigen-specific support provides an additional avenue to improve survivin-targeted, vaccination approaches.

Pre-existing anti-survivin immune responses in cancer patients do not efficiently eliminate tumor cells in part due to weak potency of such responses which may be related to immunological tolerance. One mechanism that could be exploited to break tolerance to the wild-type survivin antigen is through molecular mimicry. A molecular mimic has the ability to activate cells not deleted during central immunological development. This may include $\mathrm{T}$ cells that retain the potential to cross-react with the wild-type tumor antigens [89]. T cell clones with the capacity to be activated by self-proteins are frequently preserved following negative selection of higher affinity, selfrecognizing clones in the thymus [89]. Such potentially self-reactive cells remain tolerized under normal conditions [90]. Altered peptide ligands (mimics) can provide a way to break tolerance to the natural self-epitope $[91,92]$. Altered peptide ligands generated by substituting amino acids within a peptide epitope can markedly alter immune responses. This strategy may be used to increase the affinity of the peptide for MHC-I via alterations in the binding anchor residues $[93,94]$. While changes introduced can improve MHC class I binding, the subsequently engaging $\mathrm{T}$ cell does not always counter with an enhanced response and may lead to induction of TCR antagonism or T cell anergy [95-99]. The anti-survivin vaccine (SurVaxM) contains a large synthetic peptide with amino acid substitution designed to enhance MHC class I binding [25,57]. As a result the core epitope of SurVaxM binds HLA-A ${ }^{\star} 02$ molecules to a much greater degree than the wild-type survivin peptide leading to a more potent immune response than the wild-type survivin peptide in humans [25] (Figure 3).

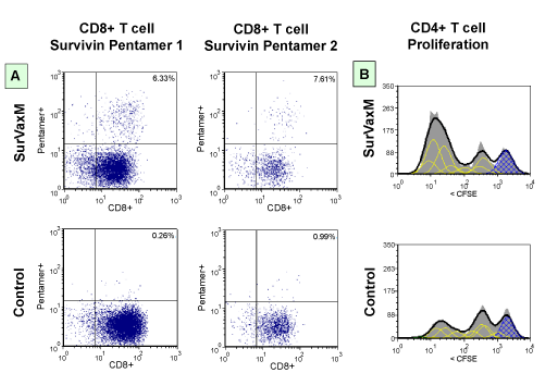

Figure 3: A) Flow cytometric analysis of pentamer binding (HLA$\left.A^{\star} 0201\right)$ to human survivin-specific CD8 $+\mathrm{T}$ cells stimulated ex vivo with SurVaxM. Specific reactivity of CD8+ T cells to two different survivin epitopes but not control peptide are shown (upper right quadrants are CD8+/Pentamer+). B) Flow cytometric measurement of $\mathrm{CD} 4+$ proliferation via CFSE dye mitotic distribution in response to ex vivo stimulation with SurVaxM. As CD4+ cells proliferate, CFSE intensity decreases as dye is redistributed among daughter cells. Stimulation was without added peptide (Control) or with SurVaxM peptide. Grey, raw data; black line, computer curve fit; blue, undivided cells; yellow line, multiple proliferative generations. Data acquisition using BD LSRFortessa and analysis using FCS express v4. [anti-survivin custom pentamer (ProImmune, Oxford, UK) and CFSE (Invitrogen-Molecular Probes, Eugene, OR)].

While designed for HLA-A ${ }^{\star} 02$ binding, the entire SurVaxM peptide contains multiple HLA- $\mathrm{A}^{\star} 02$ epitopes as well as antigen-binding motifs for HLA-A ${ }^{\star} 03$; HLA-A ${ }^{\star} 11$, A24, A26, A68, B13, B14, B15, B35, $\mathrm{B} 39$ and B44, collectively representing a large patient population in which the peptide should be immunogenic [25,57]. An amino acid substitution in SurVaxM enables this mimic to be recognized as a nonself-protein, thus eliciting a strong immune response [25]. SurVaxM stimulates a group of survivin-specific CD8+ T cells and acts as a MHC class II ligand providing CD4+ T cell stimulation [25,26,57,100]. By activating multiple CD8+ CTL responses and CD4+ helper support (Figure 3), SurVaxM has a significant theoretical advantage as an active specific immunogen compared with survivin vaccines using a single class I-restricted peptide, or ones that incorporate generic helper 
peptides, which produce non-specific helper support [25,26]. The peptide contained in SurVaxM is also located in a region common to most survivin splice variants which could allow it to simultaneously target several survivin variants. Currently SurVaxM is in Phase I clinical trials designed to study its safety, tolerability and immunological effects in patients with survivin-positive recurrent malignant gliomas and multiple myeloma [57].

\section{Conclusion}

Immunotherapy targeting survivin is still at an early stage of development; however, several agents are rapidly moving through phase I and phase II clinical trials. Recent studies demonstrate that the toxicity profile of this mode of vaccine therapy is good and that significant immune responses can be generated with some clinical responses apparent as well. Early indicators point to a strong rationale for continued study.

\section{Disclosure}

Financial \& competing interests disclosure: The trial is registered with and was approved by the US FDA and by the local IRB at Roswell Park Cancer Institute (Study I-171010) in Buffalo, NY, USA. MJC and RAF are co-founders of MimiVax, LLC, which has a financial interest in SurVaxM. The authors have no other relevant affiliations or financial involvement with any organization or entity with a financial interest in or financial conflict with the subject matter or materials discussed in the manuscript apart from those disclosed. No writing assistance was utilized in the production of this manuscript.

\section{Acknowledgements}

Portions of this work were supported by the American Cancer Society (RSG-11-153-01 to MJC); The Roswell Park Alliance Foundation; Roswell Park Cancer Institute and National Cancer Institute (NCI) grant \#P30 CA016056.

\section{References}

1. Ambrosini G, Adida C, Altieri DC (1997) A novel anti-apoptosis gene, survivin, expressed in cancer and lymphoma. Nat Med 3: 917-921.

2. Li F, Ambrosini G, Chu EY, Plescia J, Tognin S, et al. (1998) Control of apoptosis and mitotic spindle checkpoint by survivin. Nature 396: 580-584.

3. Tamm I, Wang Y, Sausville E, Scudiero DA, Vigna N, et al. (1998) IAPfamily protein survivin inhibits caspase activity and apoptosis induced by Fas (CD95), Bax, caspases, and anticancer drugs. Cancer Res 58: 5315-5320.

4. Zhao J, Tenev T, Martins LM, Downward J, Lemoine NR (2000) The ubiquitin-proteasome pathway regulates survivin degradation in a cell cycle-dependent manner. J Cell Sci 113 Pt 23: 4363-4371.

5. Fortugno P, Wall NR, Giodini A, O'Connor DS, Plescia J, et al. (2002) Survivin exists in immunochemically distinct subcellular pools and is involved in spindle microtubule function. J Cell Sci 115: 575-585.

6. Carrasco RA, Stamm NB, Marcusson E, Sandusky G, Iversen P, et al. (2011) Antisense inhibition of survivin expression as a cancer therapeutic. Mol Cancer Ther 10: 221-232.

7. Conway EM, Pollefeyt S, Cornelissen J, DeBaere I, Steiner-Mosonyi M, et al. (2000) Three differentially expressed survivin cDNA variants encode proteins with distinct antiapoptotic functions. Blood 95: 1435-1442.

8. Shin S, Sung BJ, Cho YS, Kim HJ, Ha NC, et al. (2001) An anti-apoptotic protein human survivin is a direct inhibitor of caspase-3 and -7 . Biochemistry 40: 1117-1123.
9. Kajiwara Y, Yamasaki F, Hama S, Yahara K, Yoshioka H, et al. (2003) Expression of survivin in astrocytic tumors: correlation with malignant grade and prognosis. Cancer 97: 1077-1083.

10. Islam A, Kageyama H, Takada N, Kawamoto T, Takayasu H, et al. (2000) High expression of Survivin, mapped to $17 \mathrm{q} 25$, is significantly associated with poor prognostic factors and promotes cell survival in human neuroblastoma. Oncogene 19: 617-623.

11. Altieri DC (2013) Targeting survivin in cancer. Cancer Lett 332: 225-228.

12. Altieri DC (2010) Survivin and IAP proteins in cell-death mechanisms. Biochem J 430: 199-205.

13. Li F, Brattain MG (2006) Role of the Survivin gene in pathophysiology. Am J Pathol 169: 1-11.

14. Mahotka C, Liebmann J, Wenzel M, Suschek CV, Schmitt M, et al. (2002) Differential subcellular localization of functionally divergent survivin splice variants. Cell Death Differ 9: 1334-1342.

15. Dohi T, Beltrami E, Wall NR, Plescia J, Altieri DC (2004) Mitochondrial survivin inhibits apoptosis and promotes tumorigenesis. J Clin Invest 114: 1117-1127.

16. Khan S, Jutzy JM, Valenzuela MM, Turay D, Aspe JR, et al. (2012) Plasma-derived exosomal survivin, a plausible biomarker for early detection of prostate cancer. PLoS One 7: e46737.

17. Khan S, Jutzy JM, Aspe JR, McGregor DW, Neidigh JW, et al. (2011) Survivin is released from cancer cells via exosomes. Apoptosis 16: 1-12.

18. Hoffmann AC, Warnecke-Eberz U, Luebke T, Prenzel K, Metzger R, et al. (2007) Survivin mRNA in peripheral blood is frequently detected and significantly decreased following resection of gastrointestinal cancers. J Surg Oncol 95: 51-54.

19. Hoffmann AC, Vallböhmer D, Grimminger P, Metzger R, Prenzel KL, et al. (2010) Preoperative survivin mRNA detection in peripheral blood is an independent predictor of outcome in esophageal carcinoma. Pharmacogenomics 11: 341-347.

20. Adida C, Crotty PL, McGrath J, Berrebi D, Diebold J, et al. (1998) Developmentally regulated expression of the novel cancer anti-apoptosis gene survivin in human and mouse differentiation. Am J Pathol 152: 43-49.

21. Ciesielski MJ, Apfel L, Barone TA, Castro CA, Weiss TC, et al. (2006) Antitumor effects of a xenogeneic survivin bone marrow derived dendritic cell vaccine against murine GL261 gliomas. Cancer Immunol Immunother 55: 1491-1503.

22. Satoh K, Kaneko K, Hirota M, Masamune A, Satoh A, et al. (2001) Expression of survivin is correlated with cancer cell apoptosis and is involved in the development of human pancreatic duct cell tumors. Cancer 92: 271-278.

23. Altieri DC (2003) Validating survivin as a cancer therapeutic target. Nat Rev Cancer 3: 46-54.

24. Andersen MH, thor SP (2002) Survivin--a universal tumor antigen. Histol Histopathol 17: 669-675.

25. Ciesielski MJ, Ahluwalia MS, Munich SA, Orton M, Barone T, et al. (2010) Antitumor cytotoxic T-cell response induced by a survivin peptide mimic. Cancer Immunol Immunother 59: 1211-1221.

26. Ciesielski MJ, Kozbor D, Castanaro CA, Barone TA, Fenstermaker RA (2008) Therapeutic effect of a T helper cell supported CTL response induced by a survivin peptide vaccine against murine cerebral glioma. Cancer Immunol Immunother 57: 1827-1835.

27. Mahalingam D, Medina EC, Esquivel JA, Espitia CM, Smith S, et al. (2010) Vorinostat enhances the activity of temsirolimus in renal cell carcinoma through suppression of survivin levels. Clin Cancer Res 16: 141-153.

28. Zhang W, Chen X, Qiu F (2003) An antisense plasmid targeting survivin expression induces apoptosis and sensitizes hepatocarcinoma cells to chemotherapy. J Huazhong Univ Sci Technolog Med Sci 23: 387-391.

29. Li HL, Ma AN (2010) Induction of apoptosis of non-small cell lung cancer by a methylated oligonucleotide targeting survivin gene. Cancer Gene Ther 17: 441-446. 
30. Wesierska-Gadek J, Schmid G (2007) Transcriptional repression of antiapoptotic proteins mediated by the tumor suppressor protein p53. Cancer Ther 5: 203-212.

31. UniProt Consortium (2014) Activities at the Universal Protein Resource (UniProt). Nucleic Acids Res 42: D191-198.

32. Zheng W, Ma X, Wei D, Wang T, Ma Y, et al. (2005) Molecular cloning and bioinformatics analysis of a novel spliced variant of survivin from human breast cancer cells. DNA Seq 16: 321-328.

33. Krieg A, Mahotka C, Krieg T, Grabsch H, Müller W, et al. (2002) Expression of different survivin variants in gastric carcinomas: first clues to a role of survivin-2B in tumour progression. Br J Cancer 86: 737-743.

34. Takashima H, Nakajima T, Moriguchi M, Sekoguchi S, Nishikawa T, et al. (2005) In vivo expression patterns of survivin and its splicing variants in chronic liver disease and hepatocellular carcinoma. Liver Int 25: 77-84.

35. Wagner, Schmelz K, Wuchter C, Ludwig WD, Dörken B, et al. (2006) In vivo expression of survivin and its splice variant survivin-2B: impact on clinical outcome in acute myeloid leukemia. Int J Cancer 119: 1291-1297.

36. Caldas H, Jiang Y, Holloway MP, Fangusaro J, Mahotka C, et al. (2005) Survivin splice variants regulate the balance between proliferation and cell death. Oncogene 24: 1994-2007.

37. Vivas-Mejia PE, Rodriguez-Aguayo C, Han HD, Shahzad MM, Valiyeva F, et al. (2011) Silencing survivin splice variant $2 B$ leads to antitumor activity in taxane--resistant ovarian cancer. Clin Cancer Res 17: 3716-3726.

38. Ling X, Cheng Q, Black JD, Li F (2007) Forced expression of survivin-2B abrogates mitotic cells and induces mitochondria-dependent apoptosis by blockade of tubulin polymerization and modulation of Bcl-2, Bax, and survivin. J Biol Chem 282: 27204-27214.

39. Atlasi Y, Mowla SJ, Ziaee SA (2009) Differential expression of survivin and its splice variants, survivin-DeltaEx 3 and survivin-2B, in bladder cancer. Cancer Detect Prev 32: 308-313.

40. Cheng Z, Hu L, Fu W, Zhang Q, Liao X (2007) Expression of survivin and its splice variants in gastric cancer. J Huazhong Univ Sci Technolog Med Sci 27: 393-398.

41. Mahotka C, Wenzel M, Springer E, Gabbert HE, Gerharz CD (1999) Survivin-deltaEx3 and survivin-2B: two novel splice variants of the apoptosis inhibitor survivin with different antiapoptotic properties. Cancer Res 59: 6097-6102.

42. Li F (2005) Role of survivin and its splice variants in tumorigenesis. $\mathrm{Br}$ Cancer 92: 212-216

43. Moore AS, Alonzo TA, Gerbing RB, Lange BJ, Heerema NA, et al. (2014) BIRC5 (survivin) splice variant expression correlates with refractory disease and poor outcome in pediatric acute myeloid leukemia: A report from the Children's Oncology Group. Pediatr Blood Cancer 61: 647-652.

44. Cho GS, Ahn TS, Jeong D, Kim JJ, Kim CJ, et al. (2011) Expression of the survivin-2B splice variant related to the progression of colorectal carcinoma. J Korean Surg Soc 80: 404-411.

45. Mahotka C, Krieg T, Krieg A, Wenzel M, Suschek CV, et al. (2002) Distinct in vivo expression patterns of survivin splice variants in renal cell carcinomas. Int J Cancer 100: 30-36.

46. Mull AN, Klar A, Navara CS2 (2014) Differential localization and high expression of SURVIVIN splice variants in human embryonic stem cells but not in differentiated cells implicate a role for SURVIVIN in pluripotency. Stem Cell Res 12: 539-549.

47. Marioni G, Agostini M, Bedin C, Blandamura S, Stellini E, et al. (2012) Survivin and laryngeal carcinoma prognosis: nuclear localization and expression of splice variants. Histopathology 61: 247-256.

48. Caldas H, Honsey LE, Altura RA (2005) Survivin 2alpha: a novel Survivin splice variant expressed in human malignancies. Mol Cancer 4: 11.

49. Badran A, Yoshida A, Ishikawa K, Goi T, Yamaguchi A, et al. (2004) Identification of a novel splice variant of the human anti-apoptopsis gene survivin. Biochem Biophys Res Commun 314: 902-907.

50. Jacob NK, Cooley JV, Shirai K, Chakravarti A (2012) Survivin splice variants are not essential for mitotic progression or inhibition of apoptosis induced by doxorubicin and radiation. Onco Targets Ther 5: 7-20.

51. Small TW, Pickering JG (2009) Nuclear degradation of Wilms tumor 1associating protein and survivin splice variant switching underlie IGF-1mediated survival. J Biol Chem 284: 24684-24695.

52. Luwor RB, Johns TG, Murone C, Huang HJ, Cavenee WK, et al. (2001) Monoclonal antibody 806 inhibits the growth of tumor xenografts expressing either the de2-7 or amplified epidermal growth factor receptor (EGFR) but not wild-type EGFR. Cancer Res 61: 5355-5361.

53. Wikstrand CJ, Hale LP, Batra SK, Hill ML, Humphrey PA, et al. (1995) Monoclonal antibodies against EGFRvIII are tumor specific and react with breast and lung carcinomas and malignant gliomas. Cancer Res 55: 3140-3148.

54. Dela Cruz CS, Chamberlain JW, MacDonald KS, Barber BH (1999) Xenogeneic and allogeneic anti-MHC immune responses induced by plasmid DNA immunization. Vaccine 17: 2479-2492.

55. Ciesielski MJ, Kazim AL, Barth RF, Fenstermaker RA (2005) Cellular antitumor immune response to a branched lysine multiple antigenic peptide containing epitopes of a common tumor-specific antigen in a rat glioma model. Cancer Immunol Immunother 54: 107-119.

56. Yang W, Barth RF, Wu G, Ciesielski MJ, Fenstermaker RA, et al. (2005) Development of a syngeneic rat brain tumor model expressing EGFRvIII and its use for molecular targeting studies with monoclonal antibody L8A4. Clin Cancer Res 11: 341-350.

57. Fenstermaker RA, Ciesielski MJ (2014) Challenges in the development of a survivin vaccine (SurVaxM) for malignant glioma. Expert Rev Vaccines 13: 377-385.

58. Godet Y, Bonnin A, Guilloux Y, Vignard V, Schadendorf D, et al. (2009) A new tyrosinase epitope recognized in the HLA-B ${ }^{\star} 4002$ context by CTL from melanoma patients. Cancer Immunol Immunother 58: 271-280.

59. Andersen MH, Pedersen LO, Capeller B, Bröcker EB, Becker JC, et al. (2001) Spontaneous cytotoxic T-cell responses against survivin-derived MHC class I-restricted T-cell epitopes in situ as well as ex vivo in cancer patients. Cancer Res 61: 5964-5968.

60. Coulie PG, Brichard V, Van Pel A, Wölfel T, Schneider J, et al. (1994) A new gene coding for a differentiation antigen recognized by autologous cytolytic T lymphocytes on HLA-A2 melanomas. J Exp Med 180: 35-42.

61. Cox AL, Skipper J, Chen Y, Henderson RA, Darrow TL, et al. (1994) Identification of a peptide recognized by five melanoma-specific human cytotoxic T cell lines. Science 264: 716-719.

62. Rohayem J, Diestelkoetter P, Weigle B, Oehmichen A, Schmitz M, et al. (2000) Antibody response to the tumor-associated inhibitor of apoptosis protein survivin in cancer patients. Cancer Res 60: 1815-1817.

63. Hadrup SR, Gehl J, Sørensen RB, Geertsen PF, Straten PT, et al. (2006) Persistence of survivin specific $\mathrm{T}$ cells for seven years in a melanoma patient during complete remission. Cancer Biol Ther 5: 480-482.

64. Yagihashi A, Asanuma K, Nakamura M, Araya J, Mano Y, et al. (2001) Detection of anti-survivin antibody in gastrointestinal cancer patients. Clin Chem 47: 1729-1731.

65. Karanikas V, Khalil S, Kerenidi T, Gourgoulianis KI, Germenis AE (2009) Anti-survivin antibody responses in lung cancer. Cancer Lett 282: $159-166$.

66. Reker S, Meier A, Holten-Andersen L, Svane IM, Becker JC, et al. (2004) Identification of novel survivin-derived CTL epitopes. Cancer Biol Ther 3: 173-179.

67. Hirschowitz EA, Foody T, Hidalgo GE, Yannelli JR (2007) Immunization of NSCLC patients with antigen-pulsed immature autologous dendritic cells. Lung Cancer 57: 365-372.

68. Berntsen A, Trepiakas R, Wenandy L, Geertsen PF, thor Straten P, et al. (2008) Therapeutic dendritic cell vaccination of patients with metastatic renal cell carcinoma: a clinical phase 1/2 trial. J Immunother 31: 771-780.

69. Soleimani A, Berntsen A, Svane IM, Pedersen AE (2009) Immune responses in patients with metastatic renal cell carcinoma treated with dendritic cells pulsed with tumor lysate. Scand J Immunol 70: 481-489. 
70. Hobo W, Strobbe L, Maas F, Fredrix H, Greupink-Draaisma A, et al. (2013) Immunogenicity of dendritic cells pulsed with MAGE3, Survivin and B-cell maturation antigen mRNA for vaccination of multiple myeloma patients. Cancer Immunol Immunother 62: 1381-1392.

71. Wobser M, Keikavoussi P, Kunzmann V, Weininger M, Andersen MH, et al. (2006) Complete remission of liver metastasis of pancreatic cancer under vaccination with a HLA-A2 restricted peptide derived from the universal tumor antigen survivin. Cancer Immunol Immunother 55: 1294-1298.

72. Tsuruma T, Hata F, Torigoe T, Furuhata T, Idenoue S, et al. (2004) Phase I clinical study of anti-apoptosis protein, survivin-derived peptide vaccine therapy for patients with advanced or recurrent colorectal cancer. J Transl Med 2: 19.

73. Tsuruma T, Iwayama Y, Ohmura T, Katsuramaki T, Hata F, et al. (2008) Clinical and immunological evaluation of anti-apoptosis protein survivin-derived peptide vaccine in phase I clinical study for patients with advanced or recurrent breast cancer. J Transl Med 6: 24

74. Honma I, Kitamura H, Torigoe T, Takahashi A, Tanaka T, et al. (2009) Phase I clinical study of anti-apoptosis protein survivin-derived peptide vaccination for patients with advanced or recurrent urothelial cancer. Cancer Immunol Immunother 58: 1801-1807.

75. Miyazaki A, Kobayashi J, Torigoe T, Hirohashi Y, Yamamoto T, et al. (2011) Phase I clinical trial of survivin-derived peptide vaccine therapy for patients with advanced or recurrent oral cancer. Cancer Sci 102: 324-329.

76. Tanaka M, Butler MO, Ansén S, Imataki O, Berezovskaya A, et al. (2011) Induction of HLA-DP4-restricted anti-survivin Th1 and Th2 responses using an artificial antigen-presenting cell. Clin Cancer Res 17: 5392-5401.

77. Tanaka T, Kitamura H, Inoue R, Nishida S, Takahashi-Takaya A, et al (2013) Potential survival benefit of anti-apoptosis protein: survivinderived peptide vaccine with and without interferon alpha therapy for patients with advanced or recurrent urothelial cancer--results from phase I clinical trials. Clin Dev Immunol 2013: 262967.

78. Becker JC, Andersen MH, Hofmeister-Muller V, Wobser M, Frey L, et al. (2012) Survivin-specific T-cell reactivity correlates with tumor response and patient survival: a phase-II peptide vaccination trial in metastatic melanoma. Cancer Immunol Immunother 61: 2091-2103.

79. Lennerz V, Gross S, Gallerani E, Sessa C, Mach N, et al. (2014) Immunologic response to the survivin-derived multi-epitope vaccine EMD640744 in patients with advanced solid tumors. Cancer Immunol Immunother 63: 381-394.

80. Riedmann EM (2012) Ovarian cancer vaccine candidate DPX-Survivac: positive interim results from phase 1. Hum Vaccin Immunother 8: 1743.

81. Widenmeyer M, Griesemann H, Stevanovi S, Feyerabend S, Klein R, et al. (2012) Promiscuous survivin peptide induces robust CD4+ T-cell responses in the majority of vaccinated cancer patients. Int J Cancer 131: 140-149.

82. Kim EK, Cho HI, Yoon SH, Park MJ, Sohn HJ, et al. (2008) Efficient generation of survivin-specific cytotoxic $\mathrm{T}$ lymphocytes from healthy persons in vitro: quantitative and qualitative effects of CD4+ $\mathrm{T}$ cells. Vaccine 26: 3987-3997.

83. Moeller M, Kershaw MH, Cameron R, Westwood JA, Trapani JA, et al. (2007) Sustained antigen-specific antitumor recall response mediated by gene-modified CD4+ T helper-1 and CD8+ T cells. Cancer Res 67: 11428-11437.

84. Yu J, Ren X, Cao S, Zhang W, Hao X (2006) Th1 polarization and apoptosis-inducing activity of CD4+ T -cells in cytokine-induced killers might favor the antitumor cytotoxicity of cytokine-induced killers in vivo. Cancer Biother Radiopharm 21: 276-284.

85. Pardoll DM (1999) Inducing autoimmune disease to treat cancer. Proc Natl Acad Sci U S A 96: 5340-5342.

86. Hung K, Hayashi R, Lafond-Walker A, Lowenstein C, Pardoll D, et al. (1998) The central role of CD4(+) T cells in the antitumor immune response. J Exp Med 188: 2357-2368.

87. Piesche M, Hildebrandt Y, Zettl F, Chapuy B, Schmitz M, et al. (2007) Identification of a promiscuous HLA DR-restricted T-cell epitope derived from the inhibitor of apoptosis protein survivin. Hum Immunol 68: 572-576.

88. Wang XF, Kerzerho J, Adotevi O, Nuyttens H, Badoual C, et al. (2008) Comprehensive analysis of HLA-DR- and HLA-DP4-restricted CD4+ T cell response specific for the tumor-shared antigen survivin in healthy donors and cancer patients. J Immunol 181: 431-439.

89. Overwijk WW, Restifo NP (2000) Autoimmunity and the immunotherapy of cancer: targeting the "self" to destroy the "other". Crit Rev Immunol 20: 433-450.

90. Lohr J, Knoechel B, Nagabhushanam V, Abbas AK (2005) T-cell tolerance and autoimmunity to systemic and tissue-restricted selfantigens. Immunol Rev 204: 116-127.

91. Fikes JD, Sette A (2003) Design of multi-epitope, analogue-based cancer vaccines. Expert Opin Biol Ther 3: 985-993.

92. Guevara-Patiño JA, Turk MJ, Wolchok JD, Houghton AN (2003) Immunity to cancer through immune recognition of altered self: studies with melanoma. Adv Cancer Res 90: 157-177.

93. Parkhurst MR, Salgaller ML, Southwood S, Robbins PF, Sette A, et al. (1996) Improved induction of melanoma-reactive CTL with peptides from the melanoma antigen gp100 modified at HLA-A ${ }^{\star} 0201$-binding residues. J Immunol 157: 2539-2548.

94. Valmori D, Fonteneau JF, Lizana CM, Gervois N, Liénard D, et al. (1998) Enhanced generation of specific tumor-reactive CTL in vitro by selected Melan-A/MART-1 immunodominant peptide analogues. J Immunol 160: 1750-1758.

95. Trojan A, Witzens M, Schultze JL, Vonderheide RH, Harig S, et al. (2001) Generation of cytotoxic $\mathrm{T}$ lymphocytes against native and altered peptides of human leukocyte antigen- $A^{\star} 0201$ restricted epitopes from the human epithelial cell adhesion molecule. Cancer Res 61: 4761-4765.

96. Keogh E, Fikes J, Southwood S, Celis E, Chesnut R, et al. (2001) Identification of new epitopes from four different tumor-associated antigens: recognition of naturally processed epitopes correlates with HLA-A*0201-binding affinity. J Immunol 167: 787-796.

97. Evavold BD, Sloan-Lancaster J, Allen PM (1993) Tickling the TCR: selective $\mathrm{T}$-cell functions stimulated by altered peptide ligands. Immunol Today 14: 602-609.

98. Loftus DJ, Squarcina P, Nielsen MB, Geisler C, Castelli C, et al. (1998) Peptides derived from self-proteins as partial agonists and antagonists of human CD8+ T-cell clones reactive to melanoma/melanocyte epitope MART1(27-35). Cancer Res 58: 2433-2439.

99. Rudolph MG, Stanfield RL, Wilson IA (2006) How TCRs bind MHCs, peptides, and coreceptors. Annu Rev Immunol 24: 419-466.

100. Shen L, Ciesielski M, Ramakrishnan S, Miles KM, Ellis L, et al. (2012) Class I histone deacetylase inhibitor entinostat suppresses regulatory $\mathrm{T}$ cells and enhances immunotherapies in renal and prostate cancer models. PLoS One 7: e30815. 